\title{
Funkcja profilaktyczna edukacyjnych gier komputerowych
}

\section{KEYWORDS}

video games, education, prophylaxis

\begin{abstract}
Polcyn Sylwia, Funkcja profilaktyczna edukacyjnych gier komputerowych [The prophylactic function of educational video games]. Kultura - Społeczeństwo - Edukacja nr 2(14) 2018, Poznań 2018, pp. 127-135, Adam Mickiewicz University Press. ISSN 2300-0422. DOI 10.14746/ kse.2018.14.11.
\end{abstract}

The article presents a modern look at computer games as tools and / or teaching aids used for broadly understood educational and didactic purposes at various levels of education. The author focuses mainly on the use of computer games for prophylactic purposes, and especially in counteracting various negative phenomena occurring in cyberspace.

\section{Współczesne spojrzenie na gry komputerowe}

Jeszcze kilka lat temu gry komputerowe były postrzegane niezwykle stereotypowo. Uznawano, iż wpływają negatywnie na rozwój fizyczny i psychiczny młodych użytkowników, prowadzą do desensytyzacji (odwrażliwienia) jednostki, wzrostu agresji i przyjmowania negatywnej tożsamości, wzorców i wartości przez młodych użytkowników (por. Andrzejewska, 2008; Feibel, 2006; Białokoz-Kalinowska, Piotrowska-Jastrzębska, 2005; Braun-Gałkowska, Ulfik, 2000). Jednakże - jak podaje Patrick Felicia - liczne badania wykazały, iż w przypadku prawidłowych nawyków (w tym szczególnie: przestrzegania i kontrolowania czasu poświęconego na tę formę rozrywki, weryfikacji treści gier komputerowych, odpowiedniego ich doboru do kategorii wieku użytkowników) granie może być uznane za bezpieczne, intere- 
sujące i satysfakcjonujące doświadczenie (Felicia, www). Gry komputerowe coraz częściej postrzegane są bowiem pozytywnie przez różne środowiska (naukowe, wychowawcze, edukacyjne, zawodowe) (Chmielarz, Szumski, 2016; Świątek, 2014; Kowalczyk, Brzezicka, Kossut, 2014; Filiciak, 2006). Obecnie wpisują się doskonale w kulturę popularną społeczeństwa informacyjnego opartego na strukturze sieciowej (Fiut, 2014). Przywołując również opinię Marka Krajewskiego, można określić, iż współcześnie dominująca kultura popularna jest przede wszystkim wytworem społeczeństwa nowoczesnego i ponowoczesnego, na którą składają się różne formy, a mianowicie: przedmioty, zachowania i określone sposoby życia ludzi, które, ujmowane łącznie, winny spełniać jednocześnie pięć kluczowych (nierozłącznych) warunków, takich jak:

1) być powszechnie znane i ogólnie rozpoznawalne (poprzez tradycyjne i nowe media),

2) być przedmiotem wyboru (nikt nikogo nie zmusza, by z nich korzystał),

3) być nośnikami wielu znaczeń, poddających się rozmaitym dekodowaniom,

4) być środkami porozumienia ludzi między sobą, ale i wskazywania różnic między nimi (komunikacja między jednostkami),

5) być dla różnych osób źródłem, często odmiennych, przyjemności popularnych (Fiut, 2014 za: Krawczyk, 2009).

Analizując gry komputerowe jako fenomen kultury współczesnej, kultury popularnej wpisującej się w jej podstawowe założenia, należy wyraźnie podkreślić, iż odpowiadają one każdemu z powyższych warunków wyodrębnionych przez M. Krajewskiego (Fiut, 2014 za: Krawczyk, 2009).

Obecnie z całą pewnością można także określić, iż gry komputerowe nie tylko są wykorzystywane w czasie wolnym przez dzieci i młodzież (i osoby dorosłe), stanowiąc alternatywę dla tradycyjnych form wolnoczasowych (przykładowo: uprawianie sportu, czytelnictwo, kolekcjonerstwo, modelarstwo, itd.), ale stają się jednym ze środowisk wychowawczych i socjalizacyjnych występujących w procesie umysłowego, intelektualnego, emocjonalnego rozwoju dziecka i młodzieży, ich inicjacji z estetyką i etyką, edukacją i pracą. Jak trafnie podkreśla Mirosława Wawrzak-Chodaczek „świat wirtualnej rzeczywistości coraz wierniej oddaje «rzeczywistość za oknem»" (Wawrzak-Chodaczek, 2012: 238), a często wręcz ją zastępuje, stając się bardziej atrakcyjny dla młodego człowieka niż świat i rzeczywistość realna. Nic więc dziwnego, iż widoczna granica pomiędzy światem realnym a wirtualnym współcześnie jest zaburzona.

Jednakże gry komputerowe stają się coraz częściej stosowanym narzędziem w szeroko ujętych celach edukacyjnych i dydaktycznych. Wykorzystywane są przez nauczycieli w toku lekcji w ramach różnych przedmiotów szczegółowych oraz w ra- 
mach różnych szczebli kształcenia i typów szkół jako złożony środek dydaktyczny ułatwiający realizację celów kształcenia. Te produkty growe znalazły również szerokie zastosowanie $\mathrm{w}$ rozwijaniu umiejętności w szkoleniach pracowniczych, kadrze kierowniczej oraz w edukacji na poziomie akademickim (por. Gandziarowska-Ziołecka, Berezowska i in. 2013; Bołtuć, Bołtuć, 2004; Pivec, Dziabenko, 2004; Wodecki, 2007). Ich zastosowanie w procesie kształcenia może również $\mathrm{w}$ wysokim stopniu przełamać funkcjonujący w polskim społeczeństwie stereotyp szkoły jako „najbardziej konserwatywnej instytucji społecznej” (Przybyła, 2012: 205).

\section{Gry komputerowe jako narzędzie edukacji i terapii}

Obecnie wiele środowisk naukowych, zawodowych, a przede wszystkim edukacyjnych, zwraca coraz większą uwagę na fakt, iż gry komputerowe nie tylko realizują funkcję rozrywkową, ale są także źródłem zmiany społecznej, dobrym narzędziem budowy i przebudowy tożsamości ich użytkowników (Fiut, 2014) oraz złożonym, multimedialnym środkiem dydaktycznym stosowanym w szeroko ujętej edukacji, bowiem w wysokim stopniu angażują i motywują uczestników - procesy te zaś są jednymi z ważniejszych, które mają zasadniczy wpływ na efektywność procesu kształcenia, a szczególnie procesu uczenia się uczniów. Ich walory dostrzeżono także w kształceniu dzieci i młodzieży (Kamiński, 2013). Jak trafnie zauważa Tomasz Kamiński

gry to tak naprawdę olbrzymia szansa dla instytucji edukacyjnych i nauczycieli na poprawę efektywności procesu kształcenia. Wykorzystanie odpowiednio przygotowanych gier w nauczaniu pozwala nie tylko na zwiększenie zaangażowania osób uczących się w proces dydaktyczny, ale także może pozwolić na przezwyciężenie istotnych deficytów tradycyjnych metod nauczania - przede wszystkim w wymiarze kształtowania umiejętności praktycznych i postaw. (Kamiński, 2013: 110)

Gry komputerowe dobrane celowo i świadomie do wieku, poziomu wiadomości i umiejętności uczniów, a także zgodnie z podstawowymi założeniami procesu kształcenia (podstawa programowa, program nauczania i sformułowane cele kształcenia), mogą wspomagać rozwój kompetencji kognitywnych, przestrzennych, motorycznych, informatycznych, społecznych, w tym umiejętności związanych ze współpracą i współodpowiedzialnością, kreatywnością i umiejętnościami łączenia teorii z praktyką. Dobrane odpowiednio przez nauczyciela do materiału nauczania, mogą zostać wykorzystane w toku każdej lekcji między innymi do: 
- wyjaśniania i przybliżania otaczającej rzeczywistości, pojęć, zjawisk i eksperymentów;

- prezentowania określonych reguł i prawidłowości, szczególnie poprzez formułowanie związków przyczynowo-skutkowych;

- rozwiązywania skomplikowanych i trudnych problemów (Felicia, 2009);

- usuwania lub ograniczania bezpośrednich i pośrednich przyczyn niepowodzeń szkolnych;

- wyrównywania braków w wiadomościach i umiejętnościach uczniów;

- przywracania prawidłowych postaw wobec nauki i wzbudzania motywacji do pozyskiwania nowej wiedzy i jej pogłębiania;

- usuwania określonych zaburzeń rozwojowych;

- rozwijania osobowości i umiejętności intelektualnych uczniów;

- oswajania z technologiami i komputerem (stały element edukacji medialnej) (Chełmowska, 2008).

Gry komputerowe stosowane są również jako element terapii pedagogicznej, szczególnie w zakresie terapii zaburzeń funkcji słuchu, wzroku, a także u dzieci dyslektycznych oraz z problemami logopedycznymi.

Dokonując szczegółowej analizy zastosowania gier i ich wpływu na poszczególne obszary, warto wskazać, iż:

1) w obszarze percepcyjno-motorycznym rozwijają zdolności oraz usprawniają głównie funkcje integracji percepcyjno-motorycznych, eliminują podstawowe ich zaburzenia, a przede wszystkim umożliwiają pracę z komputerem osobom upośledzonym ruchowo;

2) w obszarze zaburzeń słuchowych wspomagają kształtowanie i utrwalanie prawidłowej wymowy, eliminują jej zaburzenia, uczą poprawnej mowy oraz wyrównują deficyty i trudności w czytaniu;

3) w obszarze zaburzeń wzroku odpowiednio dobrane produkty growe obejmują terapię w zakresie usprawniania czytania oraz specyficznych trudności w czytaniu i pisaniu, kształtowania odpowiednich umiejętności gramatycznych, a także kształtowaniu umiejętności pracy z komputerem dzieci niewidomych;

4) w obszarze deficytów intelektualnych wspomagają rozwój różnego rodzaju uzdolnień, eliminują zaburzenia intelektualne, wspierają rozwój osób upośledzonych umysłowo, ułatwiają porozumiewanie się szczególnie z osobami dotkniętymi afazją, autyzmem czy nawet i udarem mózgu;

5) w obszarze psychoterapeutycznym zachęcają przede wszystkim uczniów do nauki, a tym samym mogą przeciwdziałać trudnościom występującym w procesie uczenia się (Chełmowska, 2008). 
Współczesna oferta gier komputerowych jest bardzo bogata. Powstają i rozwijają się również gry edukacyjne i terapeutyczne. Do przykładowego ich katalogu warto z całą pewnością zaliczyć: Ages of Empires II, która może wspomagać naukę historii, rozwoju strategicznego myślenia i umiejętności zarządzania zasobami, Bioscopia, skupiającą się na mitologii, kształtowaniu strategicznego myślenia i zarządzaniu finansami, Chemicus obejmującą zagadnienia z chemii, Dysleksja, obejmująca możliwość przeprowadzenia profesjonalnej diagnozy i terapii pedagogicznej oraz zajęć korekcyjno-kompensacyjnych z dziećmi objętymi ryzykiem dysleksji, Edusensus Matematyka „MatŚwiat”, skupiającą się głównie na rozwijaniu predyspozycji matematycznych oraz wspomaganiu diagnozy i terapii zaburzeń w tym zakresie, Logopedia, która pomaga w terapii dzieci z wadami wymowy i/lub zaburzeniami słuchu i komunikacji, Oregon Trail, zawierającą tematy historyczne, geograficzne, matematyczne, a także kształtującą myślenie logiczne i strategiczne, Reader Rabbit, skupiającą się głównie na czytaniu i ortografii, czy Uwaga słuchowa wspomagającą trening uwagi słuchowej itd. ${ }^{1}$.

\section{Funkcja profilakłyczna a współczesne gry komputerowe}

Wychowanie i kształcenie młodego człowieka jest ważnym elementem w jego prawidłowym rozwoju i przygotowaniu go do dorosłego życia. Zarówno środowisko rodzinne, jak i szkolne w celu przeciwdziałania niekorzystnym zjawiskom mogącym mieć bezpośredni wpływ na młodego człowieka (a także na dalsze jego życie) realizuje różne funkcje, w tym również funkcję profilaktyczną. Można ją najogólniej zdefiniować jako zapobieganie pojawieniu się lub rozwojowi niekorzystnego zjawiska (zjawisk), współcześnie również poprzez zastosowanie odpowiednio dobranych i sprofilowanych gier komputerowych o charakterze edukacyjnym zarówno wśród dzieci, jak i młodzieży. Opierając się również na definicji MRC, można określić, iż podstawowym celem działań profilaktycznych jest rozwój kompetencji intelektualnych, osobowościowych, a także społecznych młodej jednostki. Wymaga to jednak pełnej integracji środowisk wychowawczych (rodziny i szkoły). Ponadto działania profilaktyczne powinny być skupione szczególnie na:

\footnotetext{
${ }^{1}$ Pełna lista gier komercyjnych i korzyści z nich płynących jest dostępna w: Felicia, 2009: 19, dostęp: 26.01.2017, a także gier terapeutycznych i profilaktycznych na stronie http://sklep.ydp.pl, dostęp: 26.01.2017.
} 
- pomocy dzieciom i młodzieży poprzez rozwijanie ich wiedzy o negatywnych konsekwencjach różnych, niepożądanych zjawisk oraz umiejętności, które pozwolą przeciwdziałać określonym dysfunkcjom społecznym;

- promowaniu zachowań racjonalnych i holistycznie ujmujących różne typy niebezpiecznych zachowań, które mogą pośrednio i bezpośrednio dotyczyć młodego człowieka (informowanie o występowaniu różnych negatywnych problemów, a nie tylko wybranych);

- przyczynach, źródłach występowania negatywnych zjawisk wynikających ze środowiska, w którym funkcjonuje młody człowiek, a także odwoływaniu się w działaniach profilaktycznych do całego kontekstu kulturowego, społecznego, politycznego oraz historycznego;

- kształtowaniu umiejętności dokonywania przez jednostkę pozytywnych wyborów w swoim życiu i formułowania też takich planów na przyszłość;

- kształceniu i doskonaleniu osób dorosłych w zakresie działań profilaktycznych, aby szczególnie osoby znaczące dla młodego człowieka umiały we właściwy sposób przekazywać wiedzę i stawać się wzorem/autorytetem w oparciu o nowe badania naukowe i doświadczenia różnych praktyków.

Ponadto dobrze skonstruowane i prowadzone działania o charakterze profilaktycznym winny również opierać się na ich ewaluacji i sprawdzaniu rezultatów (Gaś, 2006). Większość z tych założeń mogą również spełniać odpowiednio dobrane gry komputerowe stworzone specjalnie w celach profilaktycznych.

\section{Realizacja funkcji profilaktycznej poprzez zastosowanie gier komputerowych na wybranym przykładzie}

Współcześnie gry komputerowe znajdują również swoje zastosowanie w szeroko rozumianej profilaktyce negatywnych zachowań wśród dzieci i młodzieży. Doskonałą tego egzemplifikacją wydaje się być powstający projekt profilaktyczny „Dwie strony sieci” realizowany przez Wydział Prewencji Komendy Głównej Policji w Poznaniu. Projekt powstał w ramach „Obserwatorium Zagrożeń dla Ludzi Młodych”, którego działania skupiają się głównie na diagnozowaniu aktualnych zagrożeń występujących wśród dzieci i młodzieży oraz tworzeniu różnych działań profilaktycznych w tej kategorii wiekowej (Komenda Wojewódzka Policji w Poznaniu, www).

Celem natomiast stworzenia profilaktycznej gry edukacyjnej z jednej strony jest wykorzystanie nowych mediów jako środowiska, w którym żyją i dorastają młodzi ludzie, do celów edukacyjnych, z drugiej zaś zwrócenie szczególnie uwagi na występujące w nim zagrożenia. Ponadto w trakcie rozgrywki młodzi ludzi powinni: 
- wykształcić postawę asertywną, świadomą, oraz odpowiedzialność za swoje czyny w przestrzeni wirtualnej, a także poznać możliwości występowania negatywnych konsekwencji tych zjawisk również w życiu codziennym;

- przyswoić treści o charakterze profilaktycznym oraz edukacyjno-dydaktycznym obejmującym szczególnie zagrożenia cyfrowego świata;

- poszerzyć swoją świadomość na temat występujących cyberzagrożeń oraz sposobów pozyskiwania pomocy i wsparcia w sytuacji ich wystąpienia.

Gra komputerowa będzie obejmowała kilkanaście kluczowych obszarów tematycznych związanych bezpośrednio i pośrednio z przestrzenią wirtualną, a mianowicie takich jak: wyłudzanie danych osobowych, numerów kart kredytowych, kradzież tożsamości, podszywanie się osoby dorosłej pod dziecko lub adolescenta, stosowanie gróźb, elementy stalkingu (cyberstalkingu), pedofilię, cyberagresję, fałszowanie elektronicznych dokumentów i hakowanie, uzależnienie od Internetu i nowych mediów, a także zakup środków odurzających przez Internet.

Gra będzie skierowana szczególnie do adolescentów, przeznaczona na urządzenia stacjonarne i mobilne, skonstruowana w rzucie izometrycznym, a przede wszystkim łącząca cechy gier z gatunku przygodowych i fabularnych. Wzbogacona dodatkowo minigrami i rozwiniętymi opcjami dialogowymi. W trakcie wykonywania określonych zadań gracz będzie miał możliwość zdobycia dodatkowych punktów i bonusów, które będzie mógł wykorzystać na modyfikację swojego wyglądu lub określonych umiejętności. Gra będzie miała również walor społecznościowy, w tym szczególnie możliwość zapraszania znajomych do gry, upublicznianie rankingów i własnych osiągnięć.

Finalny projekt Komendy Wojewódzkiej Policji w Poznaniu ma zostać także wykorzystywany w trakcie zajęć profilaktycznych i wychowawczych w placówkach opiekuńczo-wychowawczych prowadzonych przez twórców i realizatorów projektu „Dwie strony sieci” w kolejnych latach w celu uświadamiania młodych jednostek o zagrożeniach wiązanych ze światem wirtualnym.

\section{Podsumowanie}

Współcześnie gry komputerowe nie są postrzegane tylko jako popularna forma wolnoczasowa występująca wśród dzieci i młodzieży, ale stają się również pomocnym narzędziem, środkiem dydaktycznym stosowanym w szeroko ujętej edukacji na różnych poziomach kształcenia, typach szkół i w ramach różnych przedmiotów szczegółowych. Zastosowanie mogą znaleźć również w działaniach profilaktycznych przeciwko niekorzystnym i destrukcyjnym zjawiskom występującym 
w cyfrowym świecie (cyberzagrożenia). Projekt „Dwie strony sieci” realizowany przez Komendę Wojewódzką Policji w Poznaniu jest przykładem wykorzystania gier komputerowych w celu uświadamiania dzieci i młodzieży oraz przeciwdziałania negatywnym zjawiskom w cyberprzestrzeni i wydaje się spotkać w przyszłości z ogromnym zainteresowaniem wśród tej grupy odbiorców. Projekt ten wpisuje się także w założenia edutainment - obejmującego wspieranie procesu uczenia się w formie rozrywki, które dla młodego człowieka może być bardziej atrakcyjne niż tradycyjnie metody kształcenia.

\section{Literatura}

Andrzejewska A. (2008). (Nie) bezpieczny komputer - od euforii do uzależnienia. Warszawa.

Białokoz-Kalinowska J., Piotrowska-Jastrzębska J. (2005). Zagrożenia zdrowotne wynikające z nieracjonalnego korzystania z komputera przez dzieci i młodzież. [W:] J. Izdebska, T. Sosnowski (red.). Dziecko i media elektroniczne - nowy wymiar dzieciństwa. Komputer i Internet $w$ życiu dziecka i obraz jego dzieciństwa, t. 2. Białystok.

Bołtuć M., Bołtuć P. (2004). Inne spojrzenie na nauczanie w oparciu o gry. „E-Mentor” nr 2 (4), http:// www.e-mentor.edu.pl/artykul/index/numer/4/id/43, dostęp: 10.05.2018.

Braun-Gałkowska M., Ulfik I. (2000). Zabawa w zabijanie. Oddziaływanie przemocy prezentowanej w mediach na psychike dzieci. Warszawa.

Chełmowska E. (2008). Wykorzystanie komputera w diagnozowaniu i terapii pedagogicznej. http:// szkolnictwo.pl/index.php?id=PU9728, dostęp: 10.05.2018.

Chmielarz W., Szumski O. (2016). Efekty i skutki uczestnictwa w grach komputerowych. „Informatyka Ekonomiczna" 1(39).

Feibel T. (2006). Zabójca $w$ dziecinnym pokoju. Przemoc i gry komputerowe. Warszawa.

Felicia P. (2009). Gry wideo w szkole. Podręcznik dla nauczyciela, European Schoolnet https://edustore.eu/publikacje-edukacyjne/80-gry-wideo-w-szkole-podrecznik-dla-nauczyciela.html, dostęp: 10.05.2018.

Filiciak M. (2006). Wirtualny plac zabaw. Gry sieciowe i przemiany kultury współczesnej. Warszawa.

Fiut I.S. (2014). Gry komputerowe a rozwój kultury popularnej. [W:] J. Bierówka, K. Pokorna-Ignatowicz (red.). Media - kultura popularna - polityka Wzajemne oddziaływania i nowe zjawiska. Kraków.

Gandziarowska-Ziołecka J., Berezowska N., Topolska J., Bobrowicz M., Klimczuk A., Bac M., Chmura J. (2013). Inspiracja światem gier: jak wygląda rynek gier szkoleniowych w Polsce? „Personel i Zarządzanie" nr 3.

Gaś Z.G. (2006). Profilaktyka w szkole. Warszawa.

Kamiński T. (2013). Dlaczego studenci nie graja w gry? Zastosowanie gier w edukacji dorosłych na przykładzie nauczania zarządzania projektami. „Homo Ludens” nr 1(5).

Kowalczyk N., Brzezicka A., Kossut M. (2014). Zmiany neuroplastyczne w wyniku intensywnych treningów poznawczych: porównanie tradycyjnego podejścia i metod wykorzystujących gry komputerowe. „Neuropsychiatria i Neuropsychologia” vol. 9, nr 3-4. 
Krawczyk S. (2009). Tak, ale! RPG jako część kultury popularnej. http://esensja.pl/gry/publicystyka/ tekst.html?id=7520, dostęp: 10.05 .2018 .

Pivec M., Dziabenko O. (2004). Model gry edukacyjnej. „E-Mentor” nr 2 (4).

Przybyła M. (2012). Digital Natives vs. Digital Immigrants? - szkoła a kreatywność on-line. „Studia Edukacyjne" nr 23, s. 203-216.

Świątek P. (2014). Rodzaje gier użytkowych (serious games) oraz ich zastosowanie w edukacji - opis zjawiska. „Annales Universitatis Paedagogicae Cracoviensis. Studia de Cultura” VI, s. 95-105.

Wawrzak-Chodaczek M. (2012). Rola gier komputerowych w czasie wolnym młodzieży w wieku adolescencji, „Chowanna” nr 2, s. 237-252.

Wodecki A. (2007). Second Life Uniwersytetu, http://e-edukacja.com/czwarta/_referaty/sesja_I/03_e-edukacja.pdf, dostęp: 26.01.2017. 